\title{
The system of co-ownership in Japan ${ }^{\star}$
}

\section{Minju Kim}

Hiroshima University, 1-3-2, Kagamiyama, Higashi-Hiroshima City, Hiroshima, 739-8511, Japan

For citation: Minju Kim. 2021. “The system of co-ownership in Japan”. Vestnik of Saint Petersburg University. Law 2: 374-383. https://doi.org/10.21638/spbu14.2021.208

The system of co-ownership in civil law affects various legal relationships, such as property partnerships and co-heirs. This article introduces the general rules of the co-ownership system in the Japanese Civil Code and explains how they are applied in harmony with the regulations concerning property partnerships and co-heirs. In particular, it deals with changes to regulations concerning partnership property and co-inherited property via a recent amendment of the law of obligations and law of inheritance. There is a debate about whether partnership property is shared jointly or collectively by the partners. This article, according to the basic numerus clausus principle in the Pandekten system, suggests that collective ownership should be stipulated in part on real rights and the premise that the provisions of partnership property under the Japanese Civil Code refer to regulations reflecting the collective binding of the German Civil Code. Despite the premise that co-inherited property is shared jointly by each co-heir, some conflicts have arisen regarding the disposition of shares of co-owned things and requests for refunds of deposits by partial heirs before a formal division of inheritance. The revised civil code established new provisions to resolve these issues. However, defining "joint ownership" in terms of statutory shares is taken as a basic rule while the specific portion of co-heirs has not been determined, as noted in the article, and it results in an unfair distribution of inherited property.

Keywords: revision of Japanese civil code, co-ownership, joint ownership, collective ownership, partnership, co-inherited properties.

\section{Introduction}

The Japanese civil code, promulgated in $1896^{1}$, has been developing and changing for 120 years. Recently, the Law of Obligation and the Law of Inheritance from the Japanese civil code were significantly revised by the Amendment to Act No. 44, 20172, and the Amendment to Act no. $72,2018^{3}$, respectively. These two parts work together to modern-

* This work was supported by JSPS KAKENHI Grant-in-Aid for Early-Career Scientists No. 20K13370.

${ }^{1}$ Civil Code. Act No. 89 of 1986. Accessed January 15, 2021. https://dl.ndl.go.jp/info:ndljp/ pid/787999/92. (In Japanese)

2 Civil Code. Amendment of Act No. 44 of 2017. Accessed January 15, 2021. http://www.japaneselawtranslation.go.jp/law/detail/?id=3494\&vm=04\&re=02. (The articles of Part I, II, III of the Japanese civil code are referred to this translation site hereafter.)

3 Civil Code. Amendment of Act No. 72 of 2018. Accessed January 15, 2021. https://elaws.e-gov.go.jp/ document?lawid=129AC000000089DS. (In Japanese) The translation of this amendment by Japanese Ministry of Justice is not updated yet. Here is the translation of Part IV and V before this amendment, offered by the Japanese Ministry of Justice. Accessed January 15, 2021. http://www.japaneselawtranslation. go.jp/law/detail/? $\mathrm{ft}=2 \& \mathrm{re}=02 \& \mathrm{dn}=1 \& \mathrm{yo}=\mathrm{civil}+\& \mathrm{x}=0 \& \mathrm{y}=0 \& \mathrm{ia}=03 \& \mathrm{ja}=04 \& \mathrm{ph}=\& \mathrm{ky}=\& \mathrm{page}=16$.

(c) St. Petersburg State University, 2021 
ize the civil law system while making broad readjustments to the legal code, theories, and judicial precedents.

Currently, the Japanese judiciary committee is in the process of revising the laws on property (Part II: Real rights and Part V: Inheritance) and modifying a property registration system that can be used to adjudicate interests between co-owners (especially coheirs) and record that relationship in a system of public notice. These records can then be used to resolve issues involving unoccupied houses and abandoned land. Since the Japanese civil code has basically adopted the principle that real estate is transferred simply by manifestation of intention ${ }^{4}$, and registration of inheritance is not necessary in order to transfer the title of a property to heirs, thus, there are many cases in which ownership of valueless real estate is not reflected in the registration of immovable property.

On the surface, proposed procedural methods for resolving discrepancies between entities and public notice methods (registration) may appear able to solve specific issues, but in practice, it is necessary to adjust the system's overall structure and individual regulations by modifying the substantive law. Thus, it is necessary to consider the overall system of the Japanese civil code on co-ownership and evaluate the provisions recently revised by the 2017 and 2018 amendments.

This article introduces the basic structure of the Japanese co-ownership system. Also, chronic legal issues of the traditional system and those revised by the amendments of 2017 and 2018 are discussed. Finally, comprehensive suggestions to the current Japanese co-ownership system and the remaining considerations are provided.

\section{Basic research}

\subsection{Basic Structure of the Japanese Co-Ownership System}

Co-ownership can be established through juristic action, such as through a contract or legal provisions on accession $(\$ 244)$, mixture $(\$ 245)$, inheritance, marriage, etc. Japanese civil code, which follows the Pandekten system, regulates co-ownership with general rules found in $\$ 249$ to $\$ 264$ of Part II (Real rights).

Article 249-\$ 264 of Part II are common rules to regulate when two or more persons own one thing, referred to as 'joint ownership' or 共有 (kyōyū) in Japanese. The 16 provisions $(\$ 249-264)$ regulate internal relationships between co-owners and external relationships with third parties.

First, the co-owners' shares are presumed to be equal in principle $(\$ 250)$. When a property is in co-ownership, each co-owner may use the entire property in proportion to their share $(\$ 249)$, but no co-owner may make any alteration to the property without the consent of the other co-owners $(\$ 251)$. There are no provisions on the disposal of shares, but according to the principle of freedom of disposal of ownership by the owner, disposal of individual shares of each co-owner is allowed. While there is no provision

$4 \$ 176$ "Creation and Transfer of Real Rights". The creation and transfer of real rights shall take effect solely by the manifestations of intention of the relevant parties.

$\$ 177$ "Requirements of Perfection of Changes in Real Rights Concerning Immovable Properties". Acquisitions of, losses of and changes in real rights concerning immovable properties may not be asserted against third parties, unless the same are registered pursuant to the applicable provisions of the Real Estate Registration Act (Law No. 123 of 2004) and other laws regarding registration. 
in the Japanese civil code, scholars have determined that this can be assumed from the intention of the legislation (Kawai 2007, 434).

The particulars of the management of a co-owned property are determined by a majority agreement in accordance with the value of the shares of the co-owners, except for cases of alteration to the property $(\$ 252)$. However, any of the co-owners may perform acts of preservation alone ( $\$ 252$ proviso clause).

Each co-owner is responsible for the expenses of management and bears burdens regarding the property in co-ownership in proportion to their share. If a co-owner does not fulfill their obligations for one year, the other co-owners may acquire that co-owner's share by paying them reasonable compensation $(\$ 253)$, and if one of the co-owners holds a claim against other co-owners with respect to the property in co-ownership, the claim may be exercised against their successors ( $\$ 254)$.

If one of the co-owners waives his or her share or dies without an heir, the waived share belongs to the other co-owners ( $\$ 255)$. Each co-owner may demand the partition of the property in co-ownership at any time. However, this does not preclude a contract agreeing not to partition the property for a period not exceeding five years $(\$ 256$, para 1$)$. This contract may be renewed within five years ( $\$ 256$, para 2$)$. If no agreement is reached among co-owners with respect to the partition of property in co-ownership, a request for the partition of the same may be submitted to the court $(\$ 258$, para 1$)$. If the property in co-ownership cannot be partitioned in kind, or it is likely that the value thereof will be significantly reduced by the partition, the court may order the sale of the same at auction (\$258, para 2).

If one of the co-owners holds a claim regarding co-ownership against other co-owners, upon partition, the portion of the property in co-ownership that belongs to the obligor may be appropriated for the payment of the same ( $\$ 259$, para 1$)$. If it is necessary to sell the portion of the property in co-ownership that belongs to the obligor in order to obtain the payment referred to in the preceding paragraph, the obligee may demand the sale of the same $(\$ 259$, para 2$)$.

A person who holds a right to the property in co-ownership, or a creditor of any of the co-owners, may participate in partitions at their own expense $(\$ 260$, para 1$)$. If, despite the request for participation, the partition occurs without allowing the participation of the individual that submitted the request, that partition may not be duly asserted against the person that submitted the request ( $\$ 260$, para 2$)$.

After partition, each co-owner must provide the same warranty as that of a seller in proportion to each co-owner's share with regards to the property that the other co-owners have acquired from the partition $(\$ 261)$.

Additionally, there is a concept called 'quasi co-ownership' that, unless otherwise provided by laws and regulations, requires that if two or more persons share property rights other than ownership, the provisions of this section shall be applied mutatis mutandis $(\$ 264)$.

Otherwise, a regulation in Part III "Claims" on partnership defines the property to be co-owned by all partners ( $\$ 668)$. Part IV “Relatives" explains that a married couple's property follows the same principles of an individual's property; however, when the property does not clearly belong to either the husband or the wife, it shall be presumed to be held in co-ownership (\$762). Article 898 in Part V "Inheritance" regulates that if there are 
two or more heirs, the inherited property shall belong to those heirs in co-ownership. The Japanese also refer to this as 共有 (kyōyū), exactly the same term as in Part II.

Otherwise, there is no provision in the Japanese civil code on the property of unincorporated association, but judicial precedents have applied a theory that approves another type of co-ownership, called 総有 (sōyū; 'Gesamteigentum’ in German).

\subsection{Discussion}

\subsubsection{Relationship between Co-ownership and Partnership Property}

Partnership property is a controversial issue. A partnership is created through a certain contract typical in the Japanese Civil Code. A partnership contract requires each of the parties commit to contribute to and engage in a joint undertaking (\$667). Article 668 in the Japanese Civil Code regulates that the contributions of the partners and other partnership property are co-owned by all partners. The term “co-owned" also means 共 有 (kyōyū), as in joint ownership.

However, $₫ 676$ on the disposal of shares and division of partnership property stipulated that if a partner disposes of his/her share in the partnership property, the disposal may not be asserted upon the partnership or third parties who have had dealings with the partnership ( $\$ 676$, para 1, before the revision in 2017). A partner may not seek the division of the partnership property before the same property has been liquidated $(\$ 676$, para 2, before the revision in 2017). Therefore, the freedom to dispose of a share that is allowed in co-ownership has limitations. Before the revision in 2017, $\$ 677$ stipulated that the obligor of a partnership may not set off their obligation against their claim against the partners.

Many scholars argue that partnership property is not the same as co-ownership (joint ownership) referred to in Part II of the Japanese Civil Code because the restrictions of the provisions are contrary to the principles of freedom of disposal of shares and partitions $(\$ 256)$ expressed in the provision on co-owned property (Ishida 1932, 511; Wagatsuma 1962, 798; Shinagawa 1993, 63; Kato 2005, 294). They explain that the foundation of restrictions on freedom to share is derived from German civil law, which has similar rules in the $\mathrm{BGB}^{5} \$ 719$ (Gesamthänderische Bindung; simply translates to 'collective binding'). Japanese scholars generally call partnership property "collective ownership" (合有, gōyū; 'Gesamthandseigentum' in German).

In contrast, some scholars argue that partnership property is identical to joint ownership referred to in Part II based on the intentions of legislators. They explain that the restrictions imposed by $\$ 676$ and $\$ 677$ are just characteristics of partnership contracts intended to cooperatively maintain the business of partnership and that the conception regarding joint ownership, 共有 (kyōyū), is enough to regulate the various types of coownership, including exceptional cases. They further argue that the Japanese legislators who introduced these structures and regulations intended for partnership property to be ruled upon according to the principles of joint ownership (Mishima 1964, 34; Hoshino 1967, 79; Mukawa 2014, 718).

${ }^{5}$ BGB. German Civil Code. Accessed January 15, 2021. https://www.gesetze-im-internet.de/englisch_ bgb/index.html. 
Judicial precedent states that "even if the partnership property is theoretically collectively owned, the provisions of the civil code itself are stipulated in the premise of joint ownership, and there is no choice but to register the partnership-owned real estate as a jointly shared property. Thus, as an interpretation, the collective ownership of partnership property under the civil code is accompanied by restrictions as stipulated by the civil code regarding co-ownership share. Therefore, for partnership property, unless otherwise specified in $\$ 667$ and 668 of the civil code, the provisions of $\$ 249-264$ of the civil code will be applied"6. In other words, the judicial precedent interprets $\$ 667$ and $\$ 668$ in Part III as special provisions additional to $\$ 249-264$ in Part II.

In fact, in the protocol of the Japanese civil code, $\$ 676(2)$ and $\$ 677$ before the revision in 2017 could be identified as referring to the second draft of the BGB and $\$ 719^{7}$ of the current BGB, respectively, which includes the characteristics of collective ownership (Maeda, Okubo, Ishida 1991, 137). According to $\$ 676$ (1), a partner is not totally prohibited from disposing of their share of the partnership property; they are just not able to assert the disposal against the partnership and third parties. The prohibition of the division of the partnership property may be explained according to the intrinsic character of the contract for partnership to maintain common businesses. However, $₫ 676$ and 677 were ambiguous in distinguishing whether partnership property is a claim or a real right. In accordance with judicial precedents, if there is no specific regulation, provisions $\$ 249-264$ should be applied.

The revision of the law of obligation in 2017 was officially enforced on 1 April 2020, and its provisions emphasized the nature of partnership property as collective ownership. Paragraph 1 was newly added to $\$ 675$, explaining the right of the obligee of a partnership. It includes the following stipulation: "An obligee of the partnership may exercise these rights against the partnership property". Therefore, the obligation of a partnership belongs to all partners collectively as one obligation that is not divided jointly. Also, paragraph 2 was added to $₫ 676$, which was revised to state that "a partner may not independently exercise the rights with regard to a claim that is included in the partnership property based on that partner's share in the claim". This is a reflection of the traditional juristic precedent that claims belonging to a partnership property can only be exercised by all partners collectively (Shiomi 2017, 338). Furthermore, $\$ 677$ was extended to include the range of rights that the obligee of a specific partner may not exercise, from the set-off right of the claims to the overall right to the partnership property. These revisions have been interpreted as emphasizing that partnership property is identical to collective ownership (Shiomi 2017, 338).

However, because of the limitations within the obligational relationship, a fundamental change from collective ownership of a partnership property to a type of co-ownership in the law of real rights was not concretely discussed by the judiciary committee when making the revisions. The creators of this revision pointed out that "because the system of regulations about civil groups is changeable related to personality by the special Act and the Limited Liability Partnership Act, etc., the installation of rules which intensifies

${ }^{6}$ Japanese Supreme Court Judgment 1958, July 22. Accessed January 15, 2021. https://www.courts. go.jp/app/hanrei_jp/detail2?id=52841. (In Japanese)

7 BGB $\$ 719$ (1) A partner may not dispose of his share in partnership assets and in the individual items that are part of partnership assets; he is not entitled to demand division. (2) A debtor may not set off a claim he has against an individual partner against a claim that is part of the partnership assets. 
the independence of partnership property without the measure of disclosure should be cautious" 8 .

This revision supplements the shortcomings of $\$ 676$ and 677 , which did not formally consider the share as a real right. But the fundamental question of why the provision of contract has priority over the provision of real rights remains. Judicial precedent does not explain the provisions of partnership contracts intended by the proviso of $₫ 264$. How does the third party (e. g. obligee of partners) know that the disposal of the objective for the transaction is restricted because it is a partnership property? There is no legal means to indicate that something is a partnership property when the property or real estate has been internally entrusted and registered to the managers as a joint ownership.

\subsubsection{Relation of the Amendments to the Inherited Property of Co-heirs}

Article 898 on the effect of joint inheritance stipulates that "if there are two or more heirs, the inherited property shall belong to those heirs in co-ownership". The joint heirs can, at any time, divide the inherited property ( $\$ 907)$, and the division of inherited property shall have a retroactive effect from the time of the commencement of inheritance (\$ 909).

In the case of co-heirs, there is also a dispute about whether the meaning of co-ownership is joint or collective ownership, because BGB $\$ 2032 \mathrm{ff}$. applies "Gesamthänderische Bindung" to inheritance. Many scholars had supported the premise that collective ownership dominates by noting the retroactive effect of $\$ 909$. However, in 1947, the proviso of $\$ 909$ was added, requiring that the retroactive effect shall not prejudice the rights of a third party; since then, most scholars have agreed that inherited property jointly belongs to the co-heirs.

Consequently, the co-heirs may divide inherited property at any time by mutual agreement, unless doing so would affect the rights of a third party. Thus, each co-heir has a concrete share of the inherited property, one of the co-heirs can register his/her share of real immovable property as an act of preservation before the division of the inherited property (proviso of $₫ 252$ ), and the obligee of any of the co-heirs is also able to register and seize the share (in accordance with $\S 900^{9}$ ) via the right of subrogation ${ }^{10}$. However, Professor Mizuno pointed out that the current Japanese inheritance law has "a bug", such as a defect of rules, by highlighting the inevitability of the inheritance division being

${ }^{8}$ Judiciary Committee 2013. Accessed January 15, 2021. http://www.moj.go.jp/content/000107196. pdf. (In Japanese)

$9 \$ 900$. "Statutory Share in Inheritance". If there are two or more heirs of the same rank, their shares in inheritance shall be determined by the following items: (i) if a child and a spouse are heirs, the child's share in inheritance and the spouse's share in inheritance shall be one half each; (ii) if a spouse and lineal ascendant are heirs, the spouse's share in inheritance shall be two thirds, and the lineal ascendant's share in inheritance shall be one third; (iii) if a spouse and sibling(s) are heirs, the spouse's share in inheritance shall be three quarters, and the sibling's share in inheritance shall be one quarter; (iv) if there are two or more children, lineal ascendants, or siblings, the share in the inheritance of each shall be divided equally; provided that the share in inheritance of a sibling who shares only one parent with the decedent shall be one half of the share in inheritance of a sibling who shares both parents.

$10 \$ 423$. "Obligee's Subrogation Right". (1) An obligee may exercise the right vested in the obligor in order to preserve his/her own claim; provided, however, that this shall not apply to rights which are exclusive and personal to the obligor. 
unfair unless the disposal of the inheritance is prohibited after the commencement of inheritance ${ }^{11}$.

Furthermore, since there was no specific provision about belongings of inherited claims, complicated practical issues arose when dealing with deposit bonds inherited by several heirs. Most scholars and juristic precedents had interpreted this to mean that an inherited claim is automatically divided between each co-heir with the commencement of inheritance ${ }^{12}$. They hold that the inherited claim is not the object of the proceeding of inheritance division and has been applied by the rules of the obligational relationship of multiple parties ${ }^{13}$. As a result of the judicial precedents, each co-heir could request the return of the deposit by the statutory share to the banks at any time before the proceeding of the inheritance division. But banks typically require written agreement because they wish to avoid the risk of duplicate payment and difficulties arising from unaware co-heirs (Kataoka 2009, 42; Nagai 2008, 19). This has resulted in many lawsuits between co-heirs and banks.

In 2016, the Supreme Court of Japan ruled that inherited deposit bonds are not automatically divided between each co-heir and must be subject to the division process of inheritance ${ }^{14}$. There is also a supplementary opinion of the judgment (based on $₫ 264$ ) that inherited claims are not just the obligational relationship of multiple parties, but a quasico-ownership.

After this judgment, the Judiciary Committee, which worked on the revision of the law of inheritance in the Japanese Civil Code in 2018, established the right for a co-heir to request the partial return (1/3 of his statutory share) of an inherited deposit for minimum living expenses and the costs of the decedent's funeral in accordance with $₫ 909-2$. This revision has been officially enforced since 1 July $2019^{15}$.

Also, the new Japanese Civil Code added $\$ 899-2$, which describes the requirements for establishing the inherited rights against a third party in a joint inheritance. It is not the requirements for succession effect but rather for counteraction to the third party. Inheritance succession automatically occurs from the commencement of inheritance without any specific legal requirements unless the heir needs to apply renunciation ${ }^{16}$ or qualified acceptance ${ }^{17}$ of inheritance. When the portion exceeding the inheritance calculated is

11 Ministry of Justice 2017. Accessed January 15, 2021. http://www.moj.go.jp/content/001246053.pdf. (In Japanese)

12 Japanese Supreme Court Judgment. 2004. 214:13. Accessed January 15, 2021. https://www.courts. go.jp/app/hanrei_jp/detail2?id=62575. (In Japanese)

$13 \$ 427 \mathrm{ff}$. "Divisible Claims and Divisible Obligations". In cases when there is more than one obligee or obligor, unless any other intention is manifested, each obligee or each obligor shall have equally proportionate rights or obligations.

$\$ 428$. "Indivisible Claim". In cases where the subject of a claim is indivisible by its nature or due to the manifestation of intention of the parties involved, if there is more than one obligee, each obligee may demand the performance for the benefit of all obligees, and the relevant obligor may tender its performance to each obligee for the benefit of all obligees.

14 Japanese Supreme Court Judgment. 2016. 70-78:2121. Accessed January 15, 2021. https://www. courts.go.jp/app/hanrei_jp/detail2?id=86354. (In Japanese)

15 Civil Code. Amendment of Act No. 72 of 2018. Accessed January 15, 2021. https://elaws.e-gov. go.jp/document?lawid=129AC0000000089 DS. (In Japanese)

$16 \$ 915$. "Period for Acceptance or Renunciation of Inheritance". (1) An heir shall give unconditional or qualified acceptance, or renunciation, regarding inheritance within three months of the time he/she has knowledge that there has been a commencement of inheritance for him/her; provided that this period may be extended by the family court at the request of an interested party or a public prosecutor.

$17 \$ 922$. "Qualified Acceptance". An heir may accept inheritance reserving to perform the obligation or testamentary gift of the decedent only within the extent of the property obtained by inheritance. 
pursuant to the provisions about statutory share in inheritance, regardless of agreements made by the co-heirs for the division of inherited property, succession of rights by inheritance may not be asserted against third parties, unless registration or other requirements are fulfilled (para 1). Also, if the right in inheritance is a claim, when the portion exceeding the inheritance calculated is pursuant to the provisions about statutory share in inheritance, only in the case that the heir who succeeded the exceeded portion clearly notifies the content of the will about the claim to the obligor, it is considered as though all joint heirs notified that to the obligor and they may assert that claim against the third parties (para 2).

This revision is meant to protect third parties who are not privy to the internal portion of inheritance that is changeable by wills and co-heirs' agreements and establish a trust in the public notice system during the tentative state of co-ownership before the division of inheritance is completed.

\section{Conclusions}

3.1. The disputes between theories on partnership property are believed to have resulted from overlooking the fact that collective binding, a characteristic of the BGB's second draft, was reflected in Articles 676 and 677 of the Japanese Civil Code. In other words, at the time of the enactment of the Japanese Civil Code, collective binding, which is a characteristic of collective ownership, was already inherent in the provisions on partnership contracts. Similarly, the German Civil Code deals with this in the partnership contract, which is a part of law of obligations. Miteigentum (BGB $₫ 1008-$ 1011 ; joint ownership) is stipulated in the law of real rights as a type of co-ownership and Gesamthandseigentum (collective ownership) is explained only in theory (i. e., BGB does not have a provision about collective ownership).

However, in terms of the basic principles, numerus clausus, in the Pandekten system, it would be difficult to adopt this type of co-ownership (i. e., collective ownership) in theory and judicial precedents. To officially explain this as a kind of ownership, it must be stipulated in the civil code, especially in Part II, as a real right. Doing so would help promote concord between the actual legal relationship and the public notice system currently pursued in the work of revising the Japanese Civil Code and the Real Estate Registration Act. Therefore, it is possible to protect third parties from unpredictable damages and strengthen the safety of transactions by accurately disclosing (registering the specific share with information of restrictions by collective binding) the internal legal relationship of the partnership property, and subsequently groups that have co-owned properties (except for juristic persons), to the public.

Judicial precedent ${ }^{18}$ also acknowledges that "collective ownership" is theoretically appropriate for explaining the nature of the partnership property, but because of 'a lack of written provisions', avoidably, the provisions of the law of obligations are treated as special regulations prior to the provisions of the law of real rights ${ }^{19}$. This exceptional interpretation could also be rectified by properly stipulating the requirements and effects of collective ownership and specifying them under the part of real rights. The amendment of $2017 \mathrm{did}$

18 Japanese Supreme Court Judgment 1958, July 22.

19 Usually the provisions in Part II: real rights have a stronger effect than provisions in the Chapter of Contracts in Part III: claims. 
not go further due to boundaries (i. e., it only revised the law of obligations), but the revised contents themselves would not conflict with such legislative suggestions since they strengthened the characteristics of partnership property as collective ownership.

3.2. Whereas, in the BGB, partnership property and co-inheritance are commonly subject to collective binding, in Japan, co-inherited property tends to be passively interpreted (i. e., its legal nature as a collective ownership of co-heirs) because, unlike the partnership property relationship that requires common business to be run for a certain period of time, it is important for inheritance to be quickly confirmed by each heir by division. However, the freedom of division and disposition of shares by a co-heir is substantially restricted by $₫ 905^{20}$ concerning the right to recovery shares of other coheirs and $\$ 909$-2, which regulates the range of return for deposit bonds. Furthermore, the specific inherited proportion of a share that is reflected by a will, the contributory portion $^{21}$ and the legally reserved portion ${ }^{22}$, is not fixed until the end of the division procedures by consultation between all co-heirs or a judicial decision by a family court; the share of co-heirs is only provisional and uncertain.

Considering the uncertainty and modifiability of this inheritance division process, the revised civil code provides connecting treatment to co-ownership on the part of real rights externally based on statutory shares of inheritance with provisions such as $₫ 899-2$, 909-2 for the protection of third parties. This treatment appears to consider the protection of third parties rather than the regulation of partnership property that lacks public notice methods. However, it is possible that fairness among heirs may be violated in that the rules recognize the disposition of the statutory shares for individual property before the division of the inheritance is finally confirmed. Again, it should be pointed out that the internal legal relationship between co-heirs is in a provisional and changeable state, but externally, this is due to defining property relationship as "joint ownership".

$20 \$ 905$. "Recovery Right of Share of Inheritance". If one joint heir assigns his/her share of inheritance to a third party before a division of the inherited property, any other joint heir may obtain the share through the reimbursement of the value and expenses of that share and recover the share in inheritance.

$21 \$ 904-2$. "Contributory Portion". If there is a person from amongst joint heirs who has made a special contribution to the maintenance or increase of the decedent's property through the provision of labor or in the form of property relating to the decedent's business, medical treatment or nursing facility for the decedent, or other means, the total inherited property shall be deemed the value calculated by deducting the contributory portion as determined by agreement with the joint heirs from the value of the property of the decedent at the time of commencement of inheritance, and that person's share in inheritance shall be the amount of the contribution added to the share in inheritance calculated pursuant to the provisions of Articles 900 to 902 inclusive.

$22 \$ 1042$. "Entitlement and Amount of Legally Reserved Portion". (1) Heirs other than siblings shall receive, as a legally reserved portion, an amount which is multiplied by the ratio prescribed in each of the following items to the value of the property for calculating the legally reserved portion prescribed in paragraph 1 of the next article:

(i) in the case where only lineal ascendants are heirs, one third,

(ii) in cases other than that referred to in the preceding item (i), one half;

(2) If there are two or more heirs, the ratio specified in the items of the preceding paragraph (1) shall be the ratio obtained by multiplying each heir's share calculated pursuant to the provisions of Articles 900 and 901.

$\$ 1043$. “The Value of Properties to calculate Legally Reserved Portion”. (1) The value of properties to calculate the total legally reserved portion is the value of any gifts made by the decedent added to the value of the property held by the decedent at the time of commencement of inheritance, minus the entire amount of obligations. 
Japanese civil law is trying to promote the safety of transactions and fairness among group members by supplementing the rules on internal and external relationships of groups sharing properties and their public notice methods through constant discussion and revising works of law. However, I would like to suggest legislatively stipulating various types of co-ownership, such as "collective ownership", since in modern society defining various forms of co-ownership as one type of "joint ownership" is limiting as we have seen in the discussion on partnership and co-inheritance issues.

\section{References}

Hoshino, Eiichi. 1967. "About so-called association without right and capacity". Hōgakukyōkaizâshi 84-9: 1-86. (In Japanese)

Ishida, Bunjiro. 1932. Theories for law of Real right. Tokyo, Yuhikaku Publ. (In Japanese)

Kataoka, Takeshi. 2009. "Recent issues in the cases of division of Inheritance". Kosekijihō 647: 1-132. (In Japanese)

Kato, Masanobu. 2005. New big cycle of civil law. II-Law of Real rights. $2^{\text {nd }}$ ed. Tokyo, Yuhikaku Publ. (In Japanese)

Kawai, Takeshi. 2007. Japanese Civil Law Annotated, vol. 7: Real Rights. $2^{\text {nd }}$ ed. Tokyo, Yuhikaku Publ. (In Japanese)

Maeda, Tatsuaki, Okubo Kunihiko, Ishida Takeshi. 1991. "Historical materials-Law of co-ownership". Minshōhōzâshi 105-1: 126-140. (In Japanese)

Mishima, Senya. 1964. "Legal structure of partnership properties". Hōtoseiji 15-1: 33-64. (In Japanese)

Mukawa, Koji. 2014. "The theory of co-ownership". Zai no tayō-ka to minpō-gaku, eds Yoshida Katsumi, Katayama Naoya, 712-726. Tokyo, Shōjihōmu Publ. (In Japanese)

Nagai, Naoko. 2008. “The management of the cases of the partition of decedent's estate: for judges in charge of those cases for the first time". Kateisaibangêpō 60-9: 1-45. (In Japanese)

Shinagawa, Koji. 1993. Japanese Civil Law Annotated, vol. 17: Claims. $2^{\text {nd }}$ ed. Tokyo, Yuhikaku Publ. (In Japanese)

Shiomi, Yoshio. 2017. Outline of the amendment of the civil code (Law of Obligation). Tokyo, Kinyūzaiseijijyōkenkyūkai (Kinzai) Publ. (In Japanese)

Wagatsuma, Sakae. 1962. Theories for law of obligation-special rules. Tokyo, Iwanamisyoten Publ. (In Japanese)

Received: December 19, 2020

Accepted: March 15, 2021

Author's information:

Minju Kim - Doctor of Laws, Associate Professor; mjkim@hiroshima-u.ac.jp 